\title{
KARAKTERISTIK SPONGE CAKE BERBAHAN DASAR TEPUNG BERAS MERAH, HITAM DAN PUTIH DARI BEBERAPA DAERAH DI SUMATERA BARAT
}

\section{Characteristics of Sponge Cake Made from Red, Black, and White Rice Flour from Some Areas in West Sumatra}

\author{
Tuty Anggraini ${ }^{*}$, Yossie Kharisma Dewi, dan Kesuma Sayuti \\ Fakultas Teknologi Pertanian, Universitas Andalas \\ Kampus Limau Manis, Padang, Indonesia \\ *e-mail: tuty_anggraini@yahoo.co.id
}

Diterima: 1 Oktober 2017, revisi akhir: 25 Desember 2017 dan disetujui untuk diterbitkan: 27 Desember 2017

\section{ABSTRAK}

Beras berpigmen seperti beras merah dan beras hitam mengandung sejumlah komponen bioaktif, seperti senyawa flavonoid yang dapat berperan sebagai antioksidan. Namun, penggunaan beras merah dan hitam belum sepopuler beras putih sehingga perlu dilakukan suatu alternatif untuk meningkatkan pemanfaatan jenis beras tersebut guna meningkatkan asupan serat dan antioksidan. Beras merah dan beras hitam dapat dimanfaatkan sebagai bahan utama dalam pembuatan sponge cake. Sumatera Barat memiliki banyak kultivar beras hitam, merah dan putih. Penelitian ini bertujuan untuk mengetahui aktivitas antioksidan, kadar polifenol, antosianin serta karakteristik fisik sponge cake dari berbagai varietas beras merah, hitam dan putih dari beberapa daerah di Sumatera Barat. Hasil penelitian menunjukkan bahwa sponge cake beras hitam memberikan nilai antioksidan, kadar polifenol dan antosianin yang lebih tinggi, serta karakteristik fisik yang lebih baik dibanding sponge cake beras merah dan putih. Spongecake dari beras hitam varietas Solok Selatan dipilih menjadi produk terbaik dengan aktivitas antioksidan $44,94 \%$ pada konsentrasi 1000 ppm,total polifenol 13,79\% dan kandungan antosianin 10,31 mg/L.

Kata kunci: sponge cake, beras merah, beras hitam, beras putih

\begin{abstract}
Pigmented rice such as red and black rice contains bioactive compound including flavonoids that can act as antioxidants. However, the use of red and black rice has not been as popular as white rice thus need to improve the utilization of these type of rice. The alternative is conducted by increasing the fiber and antioxidant intake. Red and black rice can be utilized as the main material to make sponge cake. West Sumatera had many cultivars of black, red, and white rice. The research was aimed to know the antioxidant activity, polyphenols, anthocyanin and the physical characteristics of the sponge cake from different varieties of red, black, and white rice from some areas in West Sumatra. The results showed that the sponge cake of black rice had the highest value of antioxidants, polyphenols, and anthocyanin as well as the physical characteristics compared to sponge cake of red and white rice. Sponge cake of black rice from Solok Selatan was the best product with antioxidant activity 44.94\%, at a concentration 1000 ppm, total polyphenols $13.79 \%$, and anthocyanin content $10.31 \mathrm{mg} / \mathrm{l}$.
\end{abstract}

Keywords: sponge cake, red rice, black rice, white rice

\section{PENDAHULUAN}

Beras merupakan komoditas pangan yang memiliki peran strategis dan penting di masyarakat Indonesia. Beras selain sebagai makanan pokok, keberadaannya cukup melimpah dan sangat mudah dijangkau oleh seluruh lapisan masyarakat Indonesia. Produksi beras di Indonesia sesungguhnya begitu beragam jenis dan varietasnya, diantaranya adalah beras hitam dan beras merah. Hanya saja beras 
hitam dan beras merah belum menjadi bahan pangan pokok seperti halnya beras putih, meskipun kedua beras berwarna ini mempunyai nilai gizi tinggi (Wijaya $\mathrm{O}$, 2013).

Hasil penelitian menunjukkan bahwa beras merah dan hitam memiliki potensi antioksidan yang tinggi. Antioksidan merupakan suatu senyawa yang dapat menghambat atau mencegah proses oksidasi senyawa lain yang diakibatkan oleh adanya radikal bebas (Wildan, 2010). Telah dilakukan penelitian mengenai aktivitas antioksidan pada beras merah, hitam, dan putih dari beberapa daerah di Sumatera Barat (Anggraini et al., 2015). Sumatera Barat memiliki banyak kultivar beras hitam, merah dan putih. Di Sumatera Barat, beras merah biasanya dimasak dan dimakan dengan pisang goreng, sedangkan beras hitam diolah sebagai pangan fermentasi. Beras yang digunakan dalam penelitian (Anggraini et al., 2015) berasal dari daerah tanam yang berbeda di wilayah Sumatera Barat, diantaranya beras merah: Batu Sangkar (Sosoh 10\%), Padang Panjang, Kubang Putih, Lembah Gumanti (Sosoh 99\%), Solok, Ombilin Merah Talang (Sosoh 100\%), Painan (Sosoh 90\%), Saribu Gantang Tanjung Balik (Sosoh 100\%), Sariak Alahan Tigo dan Pasaman. Beras hitam: Painan, Batusangkar, Palembayan, Lembah Gumanti, Solok Selatan dan Sariak Alahan Tigo. Beras putih: Kuriak Batusangkar dan Seratus Hari Kamang. Untuk meningkatkan pemanfaatan berbagai jenis beras tersebut sebagai sumber antioksidan diperlukan suatu alternatif yang mengarah pada diversifikasi pangan. Alternatif yang dapat dilakukan adalah dengan menjadikan tepung beras sebagai bahan utama dalam pembuatan sponge cake. sehingga dapat meningkatkan asupan serat dan antioksidan.

Tingginya ketergantungan masyarakat Indonesia terhadap terigu dalam pembuatan cake menyebabkan meningkatnya permintaan gandum dari tahun ke tahun. Tepung terigu juga mengandung gluten yang dapat menyebabkan alergi pada orang-orang tertentu dan sulit dicerna oleh tubuh karena sifatnya yang lengket sehingga dapat menyumbat usus dan memperlambat sistem pencernaan. Kesadaran masyarakat akan gaya hidup sehat pun terus meningkat. Maka dari itu, mulai muncul varian produk seperti cake yang dibuat menggunakan tepung khusus yang tidak mengandung gluten. Salah satu bahan yang dapat digunakan sebagai pengganti tepung terigu dan gluten-free dalam pembuatan cake adalah tepung beras. Berdasarkan uraian tersebut dan hasil penelitian (Anggraini et al., 2015) maka dilakukan penelitian dengan judul Karakteristik Sponge cake Berbahan Dasar Tepung Beras Merah, Hitam dan Putih dari Beberapa Daerah di Sumatera Barat.

\section{METODOLOGI PENELITIAN}

Bahan-bahan yang digunakan dalam penelitian ini adalah beras putih, hitam dan merah dari daerah di Sumatra Barat, telur, margarine, gula pasir, kertas roti dan plastik mika. Bahan untuk analisis adalah akuades, $\mathrm{H}_{2} \mathrm{SO}_{4}, \mathrm{NaOH}-\mathrm{Na}_{2} \mathrm{~S}_{2} \mathrm{O}_{3}, \mathrm{H}_{2} \mathrm{BO}_{3}$, $\mathrm{HCl}, \mathrm{Na}_{2} \mathrm{CO}_{3}$, etanol, indikator metil merah, larutan buffer potasium klorida, larutan buffer sodium asetat, reagen 1,1-diphenyl2-picrylhydrazil (DPPH), reagen follinciocalteu.

Peralatan yang digunakan dalam penelitian meliputi Hammer mill berpenyaring 80 mesh, spektrofotometer (Shimadzu UV-1800, Kyoto, Jepang), texture analyzer TAXT Stable Micro Systems, vortex (Maxi Max 1 Type 16700).

\section{Rancangan Penelitian}

Bentuk penelitian berupa eksploratif dengan tiga ulangan. Beras dari berbagai jenis dan varietas yang digunakan dalam penelitian dibuat menjadi tepung beras sebagai bahan utama dalam pembuatan sponge cake. Pemilihan jenis dan varietas beras didasarkan pada penelitian (Anggraini et al., 2015)

\section{Pelaksanaan Penelitian Pembuatan Tepung Beras}

Beras diayak untuk menghilangkan kotoran seperti kerikil, sekam dan gabah. Beras dapat dicuci terlebih dahulu sampai bersih, kemudian direndam di dalam air selama 6 jam. Setelah itu beras ditiriskan 
dan dikeringkan sehingga dihasilkan beras lembab dan digiling sampai halus. Beras digiling menggunakan penggiling hammer mill yang berpenyaring 80 mesh dan dijemur atau dikeringkan sampai kadar air dibawah $14 \%$.

\section{Pembuatan Sponge Cake dari Tepung Beras}

Prosedur pembuatan sponge cake adalah sebagai berikut: 3 butir telur dan $150 \mathrm{~g}$ gula pasir dikocok dengan mixer hingga sebanyak $100 \mathrm{~g}$ tepung beras dimasukkan secara bertahap dan diaduk perlahan sebanyak $100 \mathrm{~g}$ margarine yang telah dilelehkan, dialirkan sedikit-sedikit ke atas adonan yang dikocok dengan kecepatan rendah hingga adonan rata. Adonan ke dalam loyang ukuran $11 \times 23 \mathrm{~cm}$ yang telah dioles margarin dan dialasi dengan kertas roti. Kemudian dikukus pada suhu $150^{\circ} \mathrm{C}$ selama \pm 25 menit.

Tabel 1. Formulasi pembuatan sponge cake pada penelitian

\begin{tabular}{lc}
\hline \multicolumn{1}{c}{ Bahan } & Jumlah \\
\hline Tepung beras & $100 \mathrm{~g}$ \\
Gula pasir & $150 \mathrm{~g}$ \\
Telur & $3 \mathrm{butir}$ \\
Margarine & $100 \mathrm{~g}$ \\
\hline
\end{tabular}

Sumber: Jyotsna et al. (2004)

\section{Prosedur Analisis}

\section{Kadar Protein \\ Metode Titrasi}

Sampel ditimbang sebanyak 1-2 g dan dimasukkan ke dalam labu kjeldahl. Kemudian ditambahkan $1,9 \mathrm{~g} \mathrm{~K}_{2} \mathrm{SO}_{4}, 40 \mathrm{mg}$ $\mathrm{HgO}, 2 \mathrm{ml} \mathrm{H}_{2} \mathrm{SO}_{4}$ dan beberapa butir batu didih. Setelah itu sampel dididihkan selama 1-1,5 jam hingga cairan berwarna jernih dan didinginkan. Hasil destruksi dipindahkan ke labu destilasi dengan mencuci labu kjeldahl 5-6 kali dengan 1-2 $\mathrm{ml}$ akuades. Ke dalam labu destilasi juga ditambah $8 \mathrm{ml}$ larutan $\mathrm{NaOH}-\mathrm{Na}_{2} \mathrm{~S}_{2} \mathrm{O}_{3}$. Sebagai penampung destilat digunakan erlenmeyer yang telah berisi $5 \mathrm{ml}$ larutan $\mathrm{H}_{2} \mathrm{BO}_{3}$ dan 3 tetes indikator metil merah. Kemudian dilakukan destilasi sampai diperoleh destilat kira-kira $20 \mathrm{ml}$ dan blanko juga dibuat dengan menggunakan akuades yang dilanjutkan dengan titrasi menggunakan 0,02 N HCl. Kandungan protein dihitung dengan menggunakan persamaan (1)

$$
\begin{aligned}
& \% \mathrm{~N}= \\
& \frac{(\mathrm{ml} \mathrm{HCl} \text { sampel }-\mathrm{ml} \mathrm{HCl} \text { blanko }) \times \mathrm{N} \mathrm{HCl} \times 14,008}{m g ~} \times 100 \% \\
& \text { mg sampel }
\end{aligned}
$$

\section{Derajat Warna Metode Munsell}

Warna setiap sampel perlakuan diukur dengan mencocokkan dan membandingkan warna sampel dengan warna pada buku Munsell colour chart. Kemudian diamati dan dicatat nilai hue, value dan chroma (Hamsah, 2013).

\section{Analisa Tekstur (Bourne, 1982)}

Pengukuran tekstur dilakukan dengan alat texture analyzer TAXT Stable Micro Systems yang langsung dihubungkan dengan program pengukuran tekstur pada komputer. Pada program pengukuran tekstur ini, alat diatur dengan mode measure force in compression, option Hold until time, Pre-test Speed $1.00 \mathrm{~mm} / \mathrm{s}$, Test Speed $1.00 \mathrm{~mm} / \mathrm{s}$, Post-test speed 10.00 $\mathrm{mm} / \mathrm{s}$, strain $25 \%$ dan chart time $60 \mathrm{~s}$.

Sampel diletakkan pada probe silinder dengan diameter $35 \mathrm{~cm}$ dan diletakkan diatas permukaan yang rata. Hasil pengukuran berupa kurva yang menyatakan elastisitas dan dinyatakan dalam persen. Pengukuran elastisitas ini dilakukan dengan membandingkan peak force minimum yakni 60 s setelah probe menyentuh sampel dengan ketinggian peak force maksimum pada saat awal probe menyentuh sampel, dikalikan $100 \%$.

\section{Uji Aktivitas Antioksidan dengan DPPH (Huang et al., 2006)}

Aktifitas antioksidan dianalisa berdasarkan kemampuannya menangkap radikal bebas (radical scavenging activity) DPPH. Sebanyak 1 gram sampel dimasukkan ke dalam $10 \mathrm{ml}$ metanol, dilakukan homogenisasi, disaring dan didapatkan ekstrak sampel. Ekstrak sampel sebanyak $2 \mathrm{ml}$ dicampur dengan $2 \mathrm{ml}$ 
larutan metanol yang mengandung 50 ppm reagen DPPH. Campuran kemudian diaduk dan didiamkan selama 30 menit di ruang gelap. Pengukuran dilakukan dengan menggunakan spektrofotometer dengan pembacaan absorbansi pada panjang gelombang $517 \mathrm{~nm}$ (persamaan 2). Blanko yang digunakan yaitu methanol.

Aktivitas Antioksidan =

(1-Abs sampel/Abs blanko) X 100\%

\section{Analisa Kadar Antosianin dengan Metoda pH-Differensial}

(Prior et al., 1998)

Analisis kadar antosianin hanya dilakukan pada sponge cake dari beras hitam. Sebanyak masing-masing $0,01 \mathrm{ml}$ sampel dimasukkan ke dalam 2 buah tabung reaksi. Reaksi pertama ditambah larutan buffer potasium klorida $0,025 \mathrm{M} \mathrm{pH}$ 1 sebanyak 4,99 $\mathrm{ml}$ dan tabung reaksi kedua ditambahkan larutan buffer sodium asetat $0,4 \mathrm{M} \mathrm{pH} 4,5$ sebanyak $4,99 \mathrm{ml}$. Pengaturan $\mathrm{pH}$ dalam pembuatan buffer potasium klorida dan sodium asetat mengunakan $\mathrm{HCl}$ pekat. Absorbansi kedua perlakuan $\mathrm{pH}$ diukur dengan spektrofotometer pada panjang gelombang $516 \mathrm{~nm}$ dan $700 \mathrm{~nm}$ setelah didiamkan selama 15 menit. Kadar antosianin selanjutnya dinyatakan dalam $\mathrm{mg}$ CyE/g sampel (CyE = Sianidin Equivalen).

\section{Uji Kandungan Total Polifenol}

(Andarwulan et al., 1999)

Kandungan total polifenol dianalisa dengan menggunakan metode Follinciocalteu. Sebanyak 0,05 ml ekstrak sampel dimasukkan ke dalam tabung reaksi, kemudian $1 \mathrm{ml}$ etanol, $5 \mathrm{ml}$ akuades, $0,5 \mathrm{ml}$ reagen follin-ciocalteu $(50 \%)$ ditambahkan ke dalam tabung reaksi dan dihomogenkan. Setelah 5 menit, ke dalam tabung reaksi tersebut ditambahkan $1 \mathrm{ml} \quad \mathrm{Na}_{2} \mathrm{CO}_{3}(5 \%)$ dan larutan dihomogenkan. Reaksi campuran didiamkan di tempat gelap dengan dibungkus menggunakan aluminium foil selama 60 menit untuk kemudian diukur nilai absorbansinya pada panjang gelombang $725 \mathrm{~nm}$. Kurva standar dibuat dengan cara yang sama dengan mengganti sampel dengan asam galat yang dibuat dalam beberapa konsentrasi. Kandungan total polifenol dinyatakan dalam $\mathrm{mg} / \mathrm{ml}$ sampel.

\section{Uji Daya Kembang}

(Sulistianing, 1995)

Prosedur uji pengembangan cake
dilakukan dengan cara diukur menggunakan lidi dengan menusukkan pada bagian tengah adonan kemudian diukur tinggi sebelum dan sesudah pemanggangan dengan persamaan (3).

$$
\% \text { pengembangan }=\frac{B-A}{A} \times 100 \%
$$

Keterangan:
$\mathrm{A}=$ Tinggi adonan sebelum pemanggangan
$\mathrm{B}=$ Tinggi adonan setelah pemanggangan

\section{Uji Organoleptik (Soekarto, 1981)}

Uji organoleptik dilakukan untuk mengetahui tingkat kesukaan atau kelayakan suatu produk agar dapat diterima oleh panelis (konsumen). Metode pengujian yang dilakukan adalah metode hedonik (uji kesukaan) meliputi: warna, aroma, tekstur dan rasa dari produk yang dihasilkan. Pengujian dilakukan oleh 20 orang panelis. Skala hedonik yang digunakan yaitu pada kisaran 1 sampai 5 . Panelis diminta memberikan penilaian berdasarkan tingkat kesukaan dan memberikan nilai mulai dari 1 untuk sangat tidak suka hingga nilai 5 untuk sangat suka.

\section{HASIL DAN PEMBAHASAN}

\section{Kadar Protein}

Gambar 1 menunjukkan bahwa nilai kadar protein sponge cake beras merah, hitam dan putih yang dihasilkan berkisar antara $5,22-8,58 \%$. Nilai kadar protein sponge cake beras hitam yang diperoleh secara keseluruhan lebih tinggi jika dibandingkan dengan sponge cake beras merah dan sponge cake beras putih. 
Nilai kadar protein tertinggi terdapat pada sponge cake beras hitam Solok Selatan (SPBH15) 8,58\% dan selisih sedikit dengan sponge cake Beras Merah Sariak Alahan Tigo (SPBM9) 8,47\%. Kadar protein sponge cake beras hitam yang diperoleh lebih tinggi dikarenakan kadar protein yang terkandung pada beras hitam secara umum lebih tinggi dibanding beras merah dan beras putih.

Kandungan protein yang bervariasi pada sponge cake dapat juga disebabkan oleh perbedaan derajat penyosohan masing-masing varietas beras. Daerah aleuron dan sub-aleuron mengandung aleurin yang kaya akan protein (Xu et al., 2016). Protein beras pecah kulit sebagian besar terdapat pada lapisan aleuron dan sebagian kecil menyebar pada embrio dan endosperm. Penggilingan dan penyosohan beras pecah kulit menjadi beras giling menyebabkan terlepasnya lapisan perikarp, tegmen dan sebagian besar lapisan aleuron dan embrio. Sehingga dengan semakin tinggi derajat sosoh, maka semakin rendah kadar protein beras tersebut.

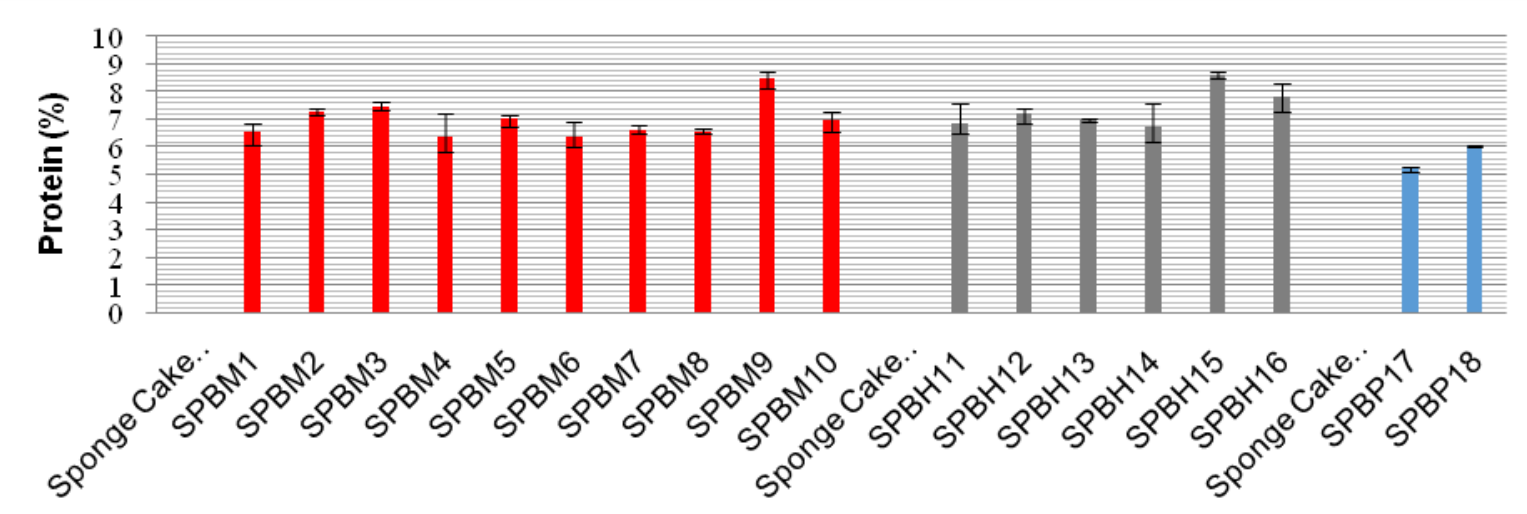

Ket:SPBM1: Beras Merah Batu Sangkar; SPBM2: Beras Merah Padang Panjang; SPBM3: Beras Merah Kubang Putih; SPBM4: Beras Merah Lembah Gumanti; SPBM5: Beras Merah Solok; SPBM6: Beras Merah Ombilin Merah Talang; SPBM7: Beras Merah Painan; SPBM8: Beras Merah Saribu Gantang Tanjung Balik; SPBM9: Beras Merah Sariak Alahan Tigo; SPBM10: Beras Merah Pasaman; SPBH11: Beras Hitam Painan; SPBH12: Beras Hitam Batu Sangkar; SPBH13: Beras Hitam Palembayan; SPBH14: Beras Hitam Lembah Gumanti; SPBH15: Beras Hitam Solok Selatan; SPBH16: Beras Hitam Sariak Alahan Tigo; SPBP17: Beras Putih Kurik Kusuik Batu Sangkar; SPBP18: Beras Putih Seratus Hari Kamang

Gambar 1. Hasil analisis kadar protein sponge cake beras merah, hitam, dan putih

Kadar protein beras meningkat setelah diolah menjadi cake, karena adanya bahan tambahan yang digunakan dalam pembuatan cake seperti telur dan margarine yang juga mengandung protein tinggi. Kadar protein sponge cake beras merah, hitam dan putih yang dihasilkan berkisar 5,22-8,58\%, telah memenuhi standar mutu kadar protein cake menurut SNI 01-3840- 1995 yaitu minimal 3\%.

\section{Derajat Warna}

Warna sponge cake ditentukan dengan membandingkan warna sponge cake tersebut dengan warna standar pada buku Munsell colour chart. Warna standar tersebut terdiri dari tiga variabel yaitu: hue, value dan chroma. Hue adalah warna spektrum yang dominan sesuai dengan panjang gelombangnya. Value menunjukkan gelap terangnya warna, sesuai dengan banyaknya sinar yang dipantulkan. Chroma menunjukkan kemurnian atau kekuatan dari warna spektrum (Hamsah, 2013). Analisa warna pada sponge cake yang dihasilkan dapat dilihat pada Tabel 2 .

Pada sistem notasi Munsell, nilai hue 2,5Y merupakan nilai paling minimum yang mengindikasikan bahwa warna yang dihasilkan paling cerah. Semakin rendah nilai Hue maka semakin cerah warna sampel. Demikian halnya dengan Value. Value dibedakan dari 0 sampai 8. Semakin tinggi value semakin cerah warna sampel 
dan angka 8 paling cerah. Chroma juga dibagi dari 0 sampai 8 , dimana semakin tinggi chroma menunjukkan kemurnian spektrum atau kekuatan warna spektrum semakin meningkat (Devi and Das, 2017).

Hasil penelitian menunjukkan, sponge cake memberikan warna yang tidak jauh dari warna bahan bakunya, yaitu beras merah, beras hitam dan beras putih. Sponge cake dari beras hitam menghasilkan warna yang cenderung gelap kecoklat-coklatan notasi 5YR dengan value 2 hingga 4, seperti brownish gray dan brownish black. Hal ini dapat terjadi karena bahan baku yang digunakan yaitu beras hitam yang berwarna ungu pekat mendekati hitam.

Tabel 2. Data analisa warna sponge cake

\begin{tabular}{|c|c|c|c|}
\hline \multirow{2}{*}{$\begin{array}{r}\text { Kode } \\
\text { Sampel }\end{array}$} & \multicolumn{2}{|c|}{ Notasi Warna } & \multirow{2}{*}{$\begin{array}{l}\text { Nama } \\
\text { Warna }\end{array}$} \\
\hline & Hue & $\mathrm{Val} / \mathrm{Chr}$ & \\
\hline SPBM1 & $2,5 \mathrm{Y}$ & $7 / 4$ & Light yellow \\
\hline SPBM2 & $2,5 \mathrm{Y}$ & $6 / 8$ & Brown \\
\hline SPBM3 & $2,5 \mathrm{Y}$ & $6 / 8$ & Brown \\
\hline SPBM4 & $5 Y$ & $8 / 4$ & Pale yellow \\
\hline SPBM5 & $2,5 \mathrm{Y}$ & $7 / 3$ & Light yellow \\
\hline SPBM6 & $5 Y$ & $8 / 4$ & Pale yellow \\
\hline SPBM7 & 7,5 YR & $6 / 6$ & Orange \\
\hline SPBM8 & $5 Y$ & $8 / 4$ & Pale yellow \\
\hline SPBM9 & $10 \mathrm{YR}$ & $4 / 6$ & Brown \\
\hline SPBM10 & $2,5 \mathrm{Y}$ & $7 / 3$ & Light yellow \\
\hline SPBH11 & $5 \mathrm{YR}$ & $4 / 1$ & $\begin{array}{l}\text { Brownish gray } \\
\text { Brownish }\end{array}$ \\
\hline SPBH12 & $5 \mathrm{YR}$ & $3 / 1$ & $\begin{array}{l}\text { black } \\
\text { Brownish }\end{array}$ \\
\hline SPBH13 & $5 \mathrm{YR}$ & $3 / 1$ & black \\
\hline SPBH14 & $5 Y R$ & $4 / 1$ & $\begin{array}{l}\text { Brownish gray } \\
\text { Brownish }\end{array}$ \\
\hline SPBH15 & $5 \mathrm{YR}$ & $2 / 1$ & $\begin{array}{l}\text { black } \\
\text { Brownish }\end{array}$ \\
\hline SPBH16 & $5 \mathrm{YR}$ & $2 / 1$ & black \\
\hline SPBP17 & $5 Y$ & $8 / 6$ & Yellow \\
\hline SPBP18 & $5 Y$ & $8 / 6$ & Yellow \\
\hline
\end{tabular}

Pada sponge cake beras merah, cake yang dihasilkan cenderung memiliki warna kuning gelap dan coklat. Hal ini dapat disebabkan karena pada sponge cake, beras merah yang digunakan ada yang telah disosoh, seperti SPBM1, SPBM4 dan SPBM8. Di pasaran terdapat beras merah sosoh atau giling dan beras merah pecah kulit murni. Beras merah sosoh atau giling memiliki warna yang lebih muda dan mengkilat, sedangkan beras pecah kulit berwarna kusam dan warna merah tua.

Adanya perlakuan penyosohan pada beras akan menyebabkan tingkat kecerahan yang semakin tinggi (putih). Hal ini dikarenakan pigmen merah (antosianin) pada beras merah banyak yang terbuang karena letaknya berada di lapisan terluar beras merah, selain itu juga karena telah terkena dampak langsung dari penyosohan. Oleh karena itu, sponge cake dari beras merah yang telah disosoh cenderung berwarna kekuning-kuningan, seperti sponge cake dari beras putih. Namun pada sponge cake dari beras merah terdapat bintik-bintik merah yang menjadi kekhas-an dari sponge cake ini. Selain itu, adanya proses pemanasan akan menyebabkan reaksi Maillard yang terjadi karena adanya interaksi pati dengan protein atau gugus amino sehingga menurunkan kecerahan pada cake yang dihasilkan.

\section{Tekstur}

Gambar 2 menunjukkan bahwa nilai tekstur sponge cake beras yang dihasilkan berkisar antara 2,90-5,96 N/cm². Sponge cake beras merah Pasaman (SPBM10) memiliki nilai tekstur tertinggi yaitu 5,96 $\mathrm{N} / \mathrm{cm}^{2}$, yang menandakan tekstur sponge cake yang dihasilkan semakin padat, sedangkan sponge cake beras hitam Painan (SPBH11) memberikan nilai tekstur terendah yaitu $2,90 \mathrm{~N} / \mathrm{cm}^{2}$, yang menandakan bahwa sponge cake dihasilkan semakin lembut.

Sponge cake dengan tepung beramilosa tinggi memberikan nilai tekstur yang tinggi atau semakin padat. Hal ini dikarenakan adanya perbedaan kandungan amilosa pada masing-masing bahan baku, mengakibatkan struktur granula pati lebih kokoh dan keras karena terkait dengan kemampuan amilosa membentuk kristal (Lii et al., 1996) Sponge cake dari beras putih memiliki kandungan amilosa yang tergolong tinggi sedangkan sponge cake dari beras hitam dan beras merah tergolong ke dalam amilosa rendah. Hal ini menjadi salah satu faktor yang 
mempengaruhi tekstur sponge cake yang dihasilkan.

Amilosa memberikan kontribusi pada pembentukan tekstur keras pada sponge cake. Menurut (Richana and Sunarti,
2004), ada hubungan positif antara tekstur dan kadar amilosa, yang berarti semakin tinggi kadar amilosa tepung dapat membentuk tekstur cake lebih keras.

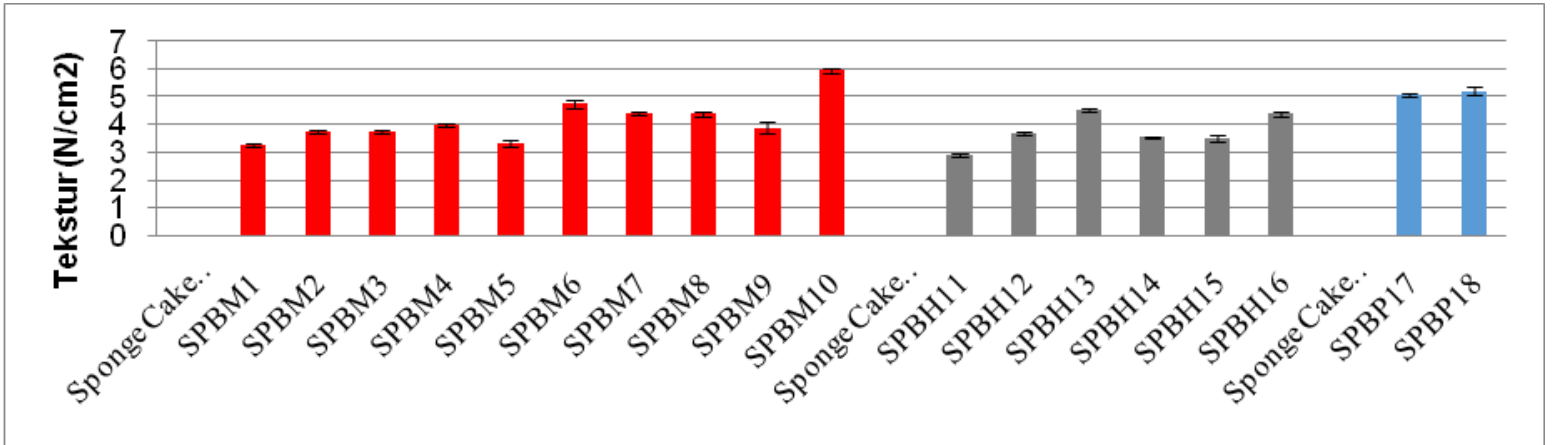

Ket:SPBM1: Beras Merah Batu Sangkar; SPBM2: Beras Merah Padang Panjang; SPBM3: Beras Merah Kubang Putih; SPBM4: Beras Merah Lembah Gumanti; SPBM5: Beras Merah Solok; SPBM6: Beras Merah Ombilin Merah Talang; SPBM7: Beras Merah Painan; SPBM8: Beras Merah Saribu Gantang Tanjung Balik; SPBM9: Beras Merah Sariak Alahan Tigo; SPBM10: Beras Merah Pasaman; SPBH11: Beras Hitam Painan; SPBH12: Beras Hitam Batu Sangkar; SPBH13: Beras Hitam Palembayan; SPBH14: Beras Hitam Lembah Gumanti; SPBH15: Beras Hitam Solok Selatan; SPBH16: Beras Hitam Sariak Alahan Tigo; SPBP17: Beras Putih Kurik Kusuik Batu Sangkar; SPBP18: Beras Putih Seratus Hari Kamang

Gambar 2. Hasil analisis tekstur sponge cake beras merah, hitam dan putih

Selain faktor tersebut, adanya keberadaan air dalam suatu produk juga akan mempengaruhi tekstur, karena air yang terdapat di dalamnya akan mempengaruhi lunak atau kerasnya suatu produk. Tekstur cake dari beras yang beramilosa tinggi memberikan nilai tekstur yang semakin tinggi atau semakin padat, dikarenakan daya kembang semakin rendah.

Tekstur berbanding terbalik dengan daya kembang, semakin tinggi nilai tekstur maka daya kembang semakin rendah dan sebaliknya (Windaryati et al., 2013). Perbandingan antara amilosa dan amilopektin akan memberikan efek pati secara fungsional dalam penggunaannya pada makanan. Contohnya dalam pemasakan dan kualitas makanan dari tepung beras. Tepung beras yang terdiri dari $99 \%$ amilopektin sangat cocok untuk membuat cake dengan tekstur yang ringan dan lembut.

\section{Aktivitas Antioksidan}

Data pada Gambar 3 menunjukkan aktivitas antioksidan yang dihasilkan sponge cake berkisar antara 12,86-44,94\% pada konsentrasi 1000 ppm, dengan aktivitas antioksidan tertinggi terdapat pada sponge cake beras hitam Solok Selatan (SPBH15), yaitu 44,94\%. Data menunjukkan bahwa secara keseluruhan kemampuan penghambatan senyawa fitokimia dalam sponge cake dari beras hitam paling tinggi dibandingkan kedua ekstrak sponge cake beras putih dan beras merah. Hal ini disebabkan beras hitam mempunyai kadar total polifenol serta antosianin yang tinggi.

Beberapa penelitian melaporkan bahwa beras memiliki senyawa bioaktif yang tinggi, diantaranya adalah tokoferol, tokotrienol, $y$-oryzanol, dan senyawa fenolik (Chakuton et al., 2012). Senyawa fitokimia seperti kandungan antosianin yang terdapat pada beras berpigmen berada pada bagian kulit terluar dari beras tersebut yaitu lapisan aleuron (Loypimai et al., 2016). Lapisan aleuron ini berbedabeda ketebalannya berdasarkan varietas, dimana beras yang berbentuk bulat pendek cenderung merupakan lapisan aleuron yang lebih tebal dibanding beras jenis lonjong panjang. Adanya proses penyosohan yang dilakukan pada beras berpigmen menurunkan kandungan 
antosianin dan senyawa fitokimia lainnya pada beras berpigmen (Anggraini et al., 2015).

Sponge cake dari beras berpigmen dengan tingkat kepekatan yang rendah cenderung menghasilkan antioksidan yang rendah, seperti SPBM1, SPBM4, SPBM6, SPBM7 dan SPBM8 pada sponge cake beras merah serta SPBH11, SPBH13 dan SPBH14 pada sponge cake beras hitam. Sementara sponge cake dari beras berpigmen dengan tingkat kepekatan yang tinggi menunjukkan kandungan antioksidan yang tinggi juga, seperti SPBM9 pada sponge cake beras merah dan SPBH15 pada sponge cake beras hitam.

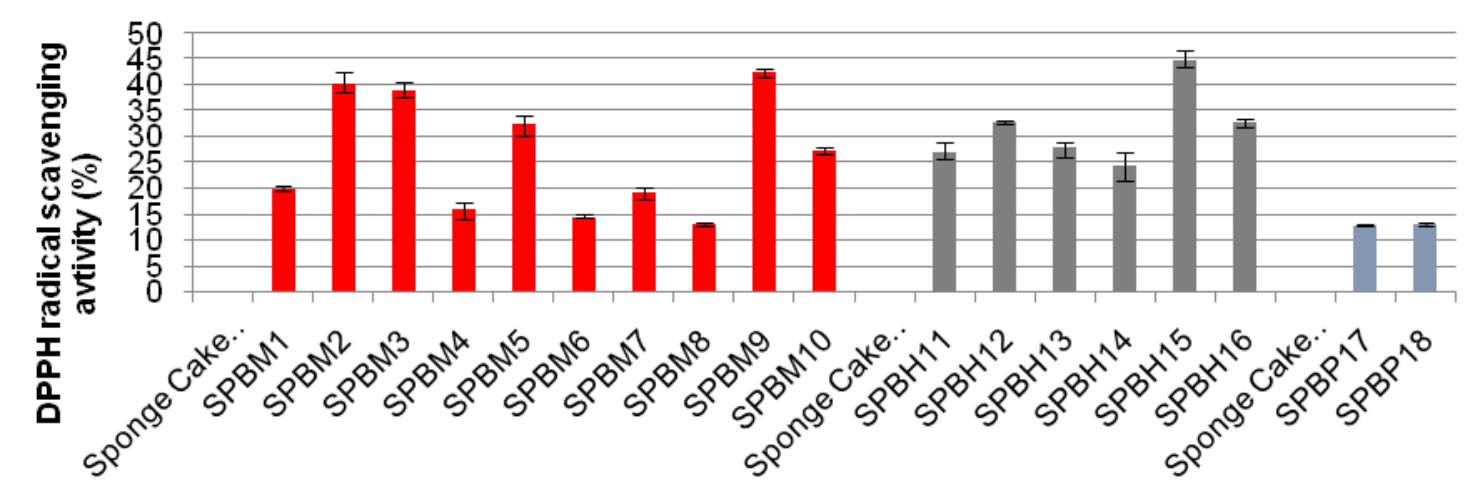

Ket:SPBM1: Beras Merah Batu Sangkar; SPBM2: Beras Merah Padang Panjang; SPBM3: Beras Merah Kubang Putih; SPBM4: Beras Merah Lembah Gumanti; SPBM5: Beras Merah Solok; SPBM6: Beras Merah Ombilin Merah Talang; SPBM7: Beras Merah Painan; SPBM8: Beras Merah Saribu Gantang Tanjung Balik; SPBM9: Beras Merah Sariak Alahan Tigo; SPBM10: Beras Merah Pasaman; SPBH11: Beras Hitam Painan; SPBH12: Beras Hitam Batu Sangkar; SPBH13: Beras Hitam Palembayan; SPBH14: Beras Hitam Lembah Gumanti; SPBH15: Beras Hitam Solok Selatan; SPBH16: Beras Hitam Sariak Alahan Tigo; SPBP17: Beras Putih Kurik Kusuik Batu Sangkar; SPBP18: Beras Putih Seratus Hari Kamang

Gambar 3. Hasil analisis antioksidan sponge cake beras merah, hitam dan putih

Selain itu, perbedaan nilai aktivitas antioksidan sponge cake dengan jenis beras yang sama namun dengan varietas yang berbeda dapat disebabkan oleh faktor eksternal beras tersebut. Kandungan fenol dapat tergantung pada varietas beras berpigmen, lokasi dibudidayakan, kondisi tumbuh, kondisi iklim, waktu panen, dan proses produksi (Lachman et al., 2009).

Tingkat kepekatan warna beras berpigmen tergantung pada konsentrasi pigmen serta derajat penyosohan beras. Semakin besar derajat penyosohan maka tingkat kepekatan warna beras akan semakin menurun sehingga semakin besar pula nutrisi pada beras yang hilang (Anggraini et al., 2015).

Penyosohan yang terlalu lama pada penggilingan padi dapat menyebabkan banyaknya lapisan aleureon yang hilang sehingga banyak kandungan antosianin dan flavonoid pada beras yang hilang. Namun, beras pecah kulit yang kaya nutrisi kurang disukai konsumen karena penampilannya kurang menarik, tekstur kasar dan susah dikunyah sehingga dilakukan proses penyosohan untuk memperbaiki penampilan beras agar lebih menarik secara visual mutu tanak, aroma dan rasanya.

\section{Kadar Antosianin}

Antosianin merupakan bagian dari flavonoid yang berperan sebagai pigmen dan bersifat antioksidatif. Senyawa antosianin dalam bentuk sianidin-3glukosida dan peonidin-3-glukosida serta turunannya merupakan senyawa yang dapat memberikan warna pada beras (Wang et al., 1997). Pada penelitian, pengujian antosianin hanya dilakukan pada sponge cake dari beras hitam.

Data pada Gambar 4 menunjukkan bahwa kandungan antosianin sponge cake beras hitam berkisar antara 5,36-10,31 $\mathrm{mg} / \mathrm{L}$. Kandungan antosianin tertinggi terdapat pada sponge cake beras hitam Solok Selatan (SPBH15), yaitu 10,31 mg/L. Beras hitam yang digunakan sebagai 
bahan baku dalam pembuatan sponge cake beras hitam, memiliki kadar antosianin yang tinggi, umumnya ditandai dengan warna beras yang lebih gelap. Sponge cake beras hitam memberikan nilai antosianin yang bervariasi. Terdapat beberapa sponge cake yang memberikan nilai antosianin yang rendah. Variasi nilai antosianin pada sponge cake ini disebabkan adanya perbedaan derajat penyosohan pada beras, seperti terlihat pada Gambar 1. Sponge cake dari beras hitam dengan tingkat kepekatan yang rendah cenderung memberikan nilai antosianin yang rendah, sedangkan sponge cake dari beras berpigmen dengan tingkat kepekatan yang tinggi memberikan nilai antosianin yang tinggi, seperti SPBH15.
Kerusakan atau kehilangan komponen fungsional, khususnya senyawa antosianin dapat terjadi pada saat proses penyosohan beras, ekstraksi pigmen dari jaringan beras, proses produksi, maupun penyimpanan produk pangan. Proses penyosohan pada beras yang dilakukan untuk menghilangkan bran layer (bekatul) akan menurunkan jumlah antosianin pada beras. Semakin besar derajat sosoh, maka semakin besar kehilangan senyawa antosianin. Kandungan antosianin akibat penyosohan dari beras pecah kulit menjadi beras giling berderajat sosoh $80 \%$ rata-rata mengalami penurunan sebanyak $17 \%$. Tingkat penurunan menjadi lebih besar $25 \%$ bila beras pecah kulit diproses menjadi beras giling berderajat sosoh 100\% (Indrasari, SD, 2010).

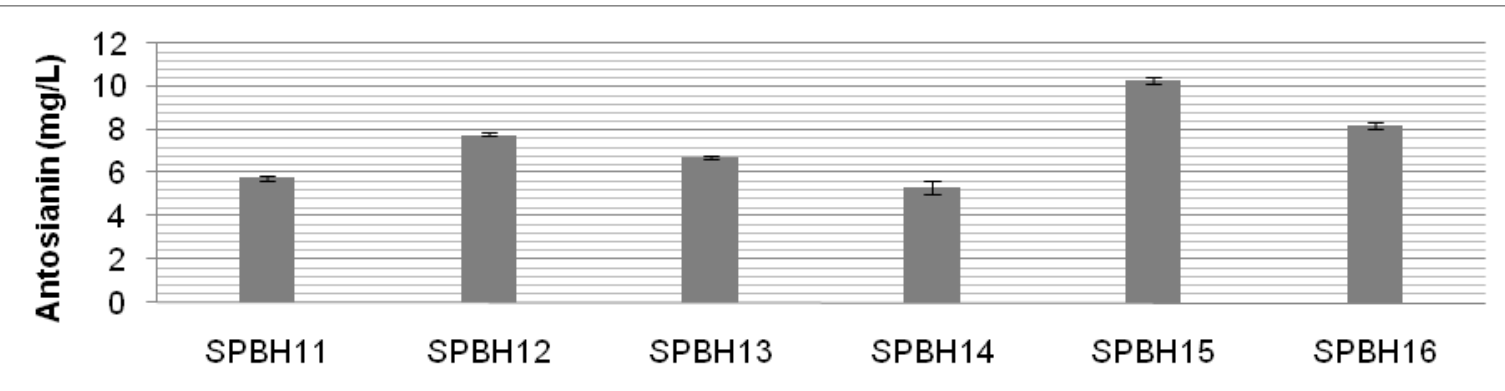

Ket: SPBH11: Beras Hitam Painan; SPBH12: Beras Hitam Batu Sangkar; SPBH13: Beras Hitam Palembayan; SPBH14: Beras Hitam Lembah Gumanti; SPBH15: Beras Hitam Solok Selatan; SPBH16: Beras Hitam Sariak Alahan Tigo

Gambar 4. Hasil analisis antosianin sponge cake beras hitam

Selain itu, perbedaan nilai antosianin sponge cake pada penelitian juga dapat disebabkan oleh perbedaan kultivar beras hitam tersebut. Hal ini terlihat dari tingkat kegelapan warna beras yang berbeda. Lingkungan tumbuh yang berbeda berpengaruh terhadap kandungan antosianin. Kandungan antosianin selain akibat pengaruh genetik juga dipengaruhi oleh faktor lingkungan yaitu $\mathrm{pH}$, tanah dan cahaya.

Antosianin yang terkandung pada beras banyak terakumulasi pada lapisan luar beras yang ditunjukkan berwarna ungu kehitaman. Suatu bahan yang mempunyai warna ungu lebih gelap, akan mempunyai kadar antosianin yang lebih tinggi pula (Sompong et al., 2011). Paling sedikit satu gugus caffeoyl asylated pada antosianin menyumbangkan aktivitas radikal yang tinggi (Suda et al., 2003). Beras hitam varietas Chiang Mai mengandung konsentrasi antosianin yang lebih tinggi $(487,25 \pm 24.36 \quad \mathrm{mg} \quad \mathrm{CyE} / \mathrm{g}$ sampel) dibanding beras merah Mali dan beras coklat Suphanburi (Pengkumsri et al., 2015). Dari hasil penelitian tersebut, tidak terdapat kandungan antosianin pada varietas beras merah Mali dan beras coklat Suphanburi yang diamati, karena pigmen antosianin lebih kaya secara intens pada beras berpigmen (beras hitam/ungu).

\section{Total Polifenol}

Data pada Gambar 5 menunjukkan bahwa total polifenol yang dihasilkan sponge cake berkisar antara 4,32-13,79\%, dengan total polifenol tertinggi terdapat pada sponge cake beras hitam solok selatan (SPBH15) yaitu 13,79\%, selanjutnya disusul dengan sponge cake 
beras merah sariak alahan tigo (SPBM9) dengan total polifenol $12,01 \%$. Sponge cake beras hitam memiliki total fenol tertinggi jika dibandingkan dengan sponge cake beras merah dan beras putih. Hal ini berarti senyawa fenolik pada sponge cake beras hitam lebih berpotensi mendonorkan elektron atau atom hidrogen. Total fenolik pada beras hitam yang diperoleh dari Cina memiliki kandungan total fenol yang lebih besar dibandingkan beras merah yang diperoleh dari daerah yang sama (Sompong et al., 2011).

Selain antosianin, beras berpigmen juga mengandung senyawa fenolik lainnya.
Kandungan total senyawa fenolik pada beras berpigmen pada beras maupun olahannya lebih besar dibandingkan kandungan total senyawa fenolik beras putih (non pigmented) (Anggraini et al., 2016, 2015). Seperti halnya aktivitas antioksidan, total polifenol pada sponge cake beras merah dan beras hitam dengan varietas yang berbeda menunjukkan nilai yang bervariasi, hal ini dapat disebabkan karena adanya perlakuan penyosohan yang berbeda-beda pada beras (merujuk pada Gambar 1).

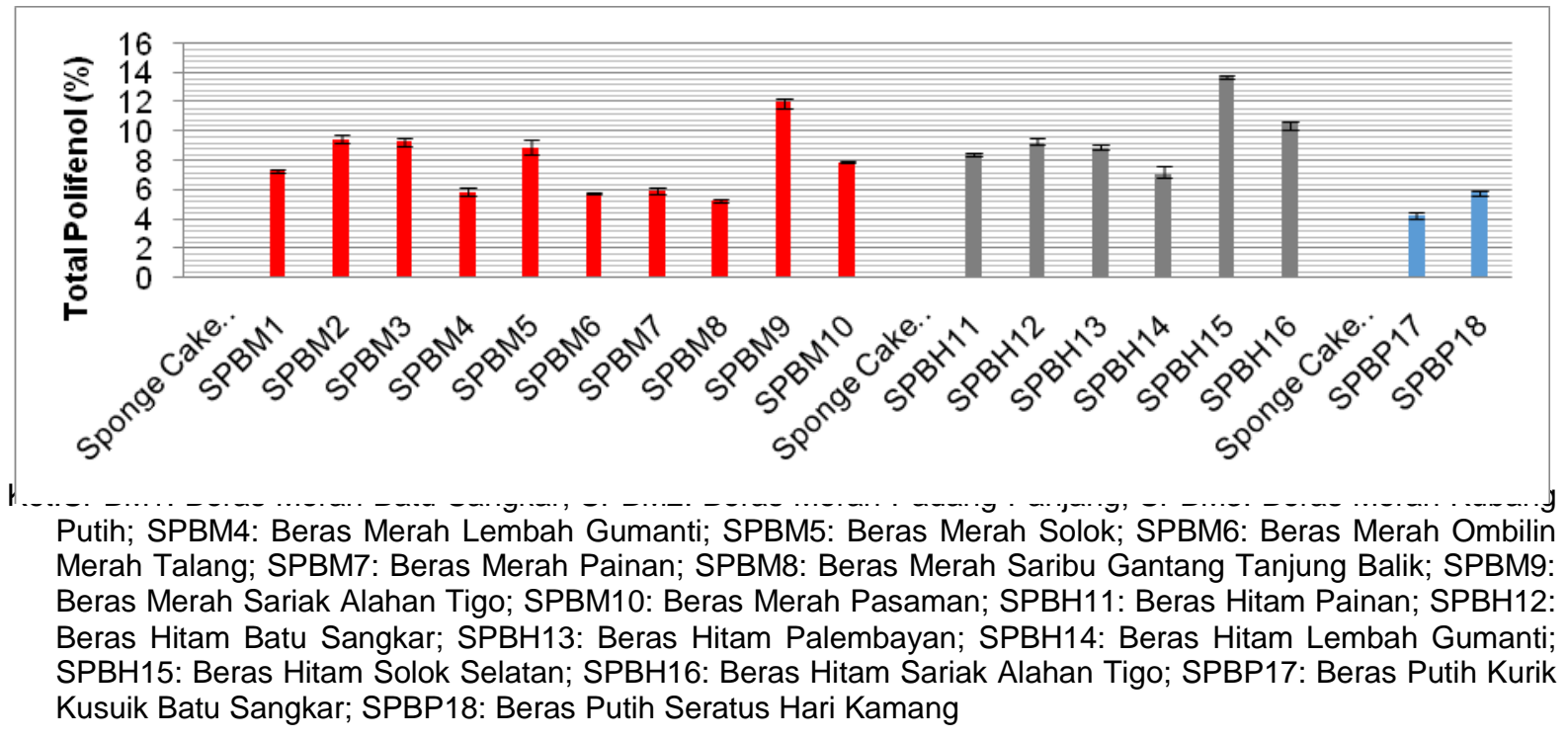

Gambar 5. Hasil analisis polifenol sponge cake beras merah, hitam dan putih

Sponge cake dari beras berpigmen dengan tingkat kepekatan yang rendah atau derajat penyosohan tinggi cenderung menghasilkan polifenol yang rendah, dan sebaliknya, sponge cake dari beras berpigmen dengan tingkat kepekatan yang tinggi atau derajat penyosohan yang rendah menunjukkan nilai polifenol yang tinggi, seperti SPBM9 pada sponge cake beras merah dan SPBH15 pada sponge cake beras hitam. Senyawa fenolik pada beras biasanya ada pada aleuron dan bran, sehingga adanya penyosohan pada beras menyebabkan total fenol pada beras menjadi rendah seperti halnya beras putih (Chakuton et al., 2012). Selain itu, perbedaan total polifenol pada masingmasing sponge cake dapat disebabkan karena varietas yang berbeda-beda dari beras yang digunakan.

\section{Daya Kembang}

Gambar 6 menunjukkan bahwa nilai daya kembang sponge cake beras yang dihasilkan berkisar antara 15,79-30\%. Sponge cake dari beras merah dan beras hitam cenderung memiliki daya kembang lebih tinggi dibanding sponge cake dari beras putih. Beras putih sebagai bahan baku sponge cake, secara umum diketahui memiliki kandungan amilosa yang lebih tinggi bila dibandingkan beras merah dan beras hitam yang digunakan dalam penelitian. Adanya perbedaan kandungan amilosa ini dapat mempengaruhi daya kembang cake yang dihasilkan. 
Cake dari bahan baku beramilosa tinggi cenderung memiliki rongga makin kecil atau makin rapat. Hal ini disebabkan amilosa mempunyai kemampuan membentuk kristal dengan ukuran lebih besar, sehingga cake tidak dapat mengembang secara baik selama pemanggangan berlangsung (Marsono, 1998). Selain itu, pengembangan volume cake juga dapat disebabkan adanya kandungan air dan nilai tekstur bahan.

Menurut Desrosier (2008), gas diperlukan untuk pengembangan adonan yang sudah tentu juga dapat berasal dari sumber lain, misalnya agensi kimia yang ditambahkan, dari uap yang ditimbulkan selama pemanggangan dan dari pengembangan gelembung udara yang meresap ke dalam campuran selama pemanggangan. Kemudian diharapkan struktur akan terbentuk pada tingkat pengembangan yang maksimum selama pemanggangan, menghasilkan tekstur dan volume yang dikehendaki. Selama proses tersebut, baik proses mixing maupun pemanggangan akan menentukan struktur cake, volume, maupun parameter kualitas lainnya (Al-Dmoor, 2013)

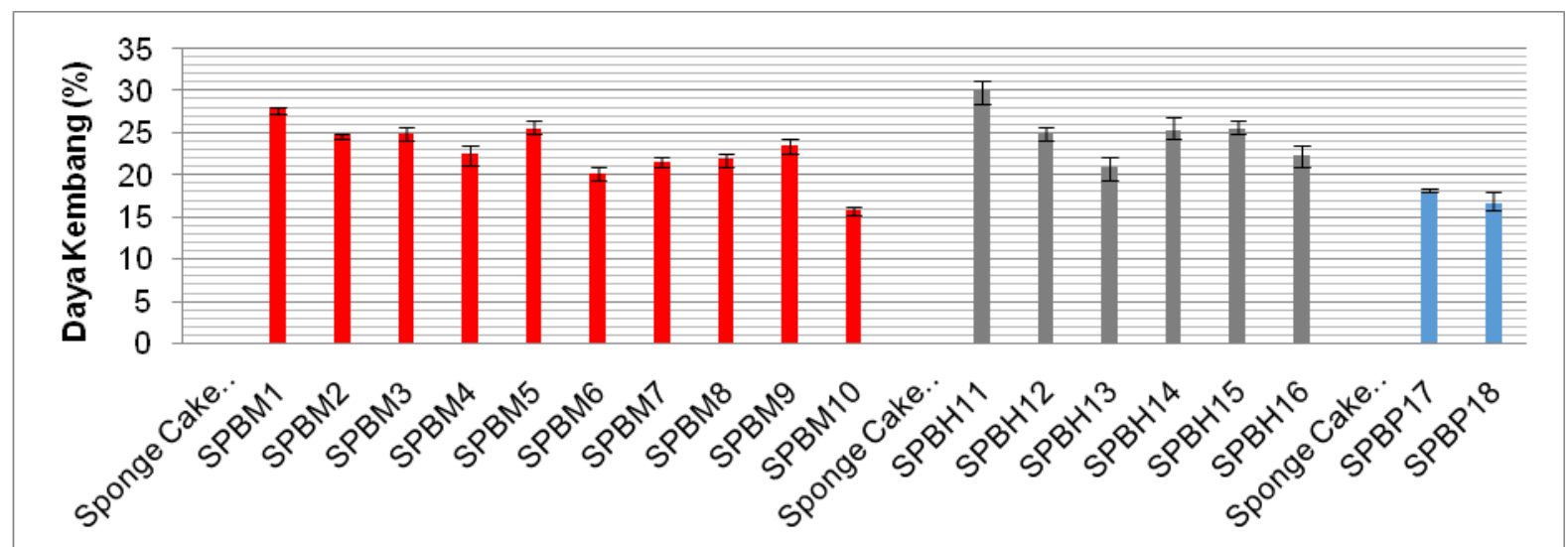

Ket:SPBM1: Beras Merah Batu Sangkar; SPBM2: Beras Merah Padang Panjang; SPBM3: Beras Merah Kubang Putih; SPBM4: Beras Merah Lembah Gumanti; SPBM5: Beras Merah Solok; SPBM6: Beras Merah Ombilin Merah Talang; SPBM7: Beras Merah Painan; SPBM8: Beras Merah Saribu Gantang Tanjung Balik; SPBM9: Beras Merah Sariak Alahan Tigo; SPBM10: Beras Merah Pasaman; SPBH11: Beras Hitam Painan; SPBH12: Beras Hitam Batu Sangkar; SPBH13: Beras Hitam Palembayan; SPBH14: Beras Hitam Lembah Gumanti; SPBH15: Beras Hitam Solok Selatan; SPBH16: Beras Hitam Sariak Alahan Tigo; SPBP17: Beras Putih Kurik Kusuik Batu Sangkar; SPBP18: Beras Putih Seratus Hari Kamang

Gambar 6. Hasil analisis daya kembang sponge cake beras merah, hitam dan putih

\section{Uji Organoleptik}

Penerimaan panelis yang menyatakan suka dan sangat suka terhadap warna, aroma, rasa, dan tekstur dapat dilihat pada Tabel 3.

\section{Warna}

Data pada Tabel 3 menunjukkan bahwa tingkat penerimaan panelis terhadap warna sponge cake beras yang dihasilkan berkisar antara 36,36-77,27\%. Secara keseluruhan, warna sponge cake yang paling disukai oleh panelis adalah sponge cake beras hitam Batu Sangkar (SPBH12) dan sponge cake beras putih Kurik Kusuik Batu Sangkar (SPBP17). Kedua cake tersebut memberikan nilai persentase tertinggi terhadap atribut warna, yaitu $77,27 \%$.

Sponge cake beras hitam Batu Sangkar (SPBH12) memiliki warna gelap yang lebih kuat dan mengkilap bila dibandingkan dengan sponge cake dari beras hitam lainnya. Hal tersebut yang mungkin menyebabkan penilaian panelis terhadap cake ini cenderung lebih tinggi. Warna gelap kuat yang diberikan cake memberikan ketertarikan kepada panelis, dikarenakan warna cake yang menyerupai brownies.

\section{Aroma}

Data pada Tabel 3 menunjukkan bahwa tingkat penerimaan panelis terhadap aroma sponge cake beras yang 
dihasilkan berkisar antara 22,73-63,64\%. Secara keseluruhan, aroma sponge cake yang paling disukai oleh panelis adalah sponge cake beras putih seratus hari Kamang (SPBP18) dengan nilai persentase $63,64 \%$.

Tabel 3. Data penerimaan panelis

\begin{tabular}{lllll}
\hline \multirow{2}{*}{ Perlakuan } & \multicolumn{4}{c}{ Menyatakan Suka dan } \\
& \multicolumn{4}{c}{ Suka $(\%)$} \\
\cline { 2 - 5 } & Aroma & Tekstur & Rasa & Warna \\
\hline SPBM1 & 54,55 & 54,55 & 54,55 & 59,09 \\
SPBM2 & 54,55 & 59,09 & 40,91 & 59,09 \\
SPBM3 & 40,91 & 50,00 & 27,27 & 50,00 \\
SPBM4 & 54,55 & 63,64 & 40,91 & 50,00 \\
SPBM5 & 50,00 & 36,36 & 45,45 & 50,00 \\
SPBM6 & 45,45 & 36,36 & 54,55 & 72,73 \\
SPBM7 & 54,55 & 54,55 & 45,45 & 40,91 \\
SPBM8 & 22,73 & 36,36 & 31,82 & 40,91 \\
SPBM9 & 36,36 & 31,82 & 27,27 & 50,00 \\
SPBM10 & 50,00 & 31,82 & 36,36 & 50,00 \\
SPBH11 & 54,55 & 27,27 & 40,91 & 72,73 \\
SPBH12 & 59,09 & 54,55 & 59,09 & 77,27 \\
SPBH13 & 50,00 & 45,45 & 54,55 & 54,55 \\
SPBH14 & 45,45 & 54,55 & 45,45 & 63,64 \\
SPBH15 & 50,00 & 54,55 & 72,73 & 36,36 \\
SPBH16 & 54,55 & 68,18 & 63,64 & 59,09 \\
SPBP17 & 54,55 & 45,45 & 50,00 & 77,27 \\
SPBP18 & 63,64 & 36,36 & 54,55 & 72,73 \\
\hline
\end{tabular}

Aroma sponge cake yang dihasilkan adalah aroma yang harum dan khas sesuai dengan bahan baku yang digunakan dalam pembuatan sponge cake, yaitu tepung beras merah, hitam dan putih. Rachmawati (2014) menyatakan bahwa komposisi pati yang banyak cukup memberikan aroma yang khas pada produk yang dihasilkan. Bahan yang banyak mengandung pati cukup memunculkan aroma tertentu pada produk, tetapi dapat dibedakan keberadaannya pada rasa produk yang dihasilkan.

\section{Rasa}

Data pada Tabel 3 menunjukkan bahwa tingkat penerimaan panelis terhadap rasa sponge cake beras yang dihasilkan berkisar antara 27,27-72,73\%.
Secara keseluruhan, rasa sponge cake yang paling disukai oleh panelis adalah sponge cake beras hitam Solok Selatan (SPBH15) dengan nilai persentase $72,73 \%$.

Tingginya persentase penerimaan panelis terhadap sponge cake disebabkan karena rasa tepung beras pada sponge cake, terutama tepung beras hitam. Tingkat rasa produk sponge cake yang dihasilkan dipengaruhi oleh penggunaan tepung beras sebagai bahan baku dan bahan tambahan lainnya, seperti jumlah penggunaan gula, lemak (margarine), telur dan bahan pemberi aroma (vanili), selain itu proses pengolahanpun tidak kalah penting, seperti proses pencampuran (mixing) dan pengukusan.

\section{Tekstur}

Data pada Tabel 3 menunjukkan bahwa tingkat penerimaan panelis terhadap tekstur sponge cake beras yang dihasilkan berkisar antara 27,27-68,18\%. Secara keseluruhan, tekstur sponge cake yang paling disukai oleh panelis adalah sponge cake beras hitam Sariak Alahan Tigo (SPBH16) dengan nilai persentase $68,18 \%$. Sponge cake beras hitam Sariak Alahan Tigo (SPBH16) disukai oleh seluruh panelis, sebab tekstur sponge cake yang dihasilkan memiliki tekstur yang lembut dan empuk atau tidak keras.

\section{KESIMPULAN}

Dari hasil penelitian diketahui bahwa sponge cake dari jenis beras dan varietas yang berbeda memberikan nilai aktivitas antioksidan, polifenol dan antosianin yang berbeda serta karakteristik fisik dan kimia cake yang berbeda pula. Secara keseluruhan, sponge cake beras hitam memberikan nilai antioksidan, polifenol kimia, kadar air dan protein dan antosianin yang lebih tinggi, serta karakteristik fisik, daya kembang dan tekstur; yang lebih baik dibanding sponge cake beras merah dan beras putih.

Sponge cake beras hitam varietas solok selatan dipilih menjadi varietas terbaik dengan aktivitas antioksidan sponge cake beras hitam varietas Solok Selatan $44,94 \%$ pada konsentrasi 1000 
ppm, total polifenol $13,79 \%$ dan kandungan antosianin 10,31 mg/l.

\section{DAFTAR PUSTAKA}

Al-Dmoor, H.M., 2013. Cake flour: functionality and quality (Review). Eur. Sci. J. 9, 1857-7881.

Andarwulan, N., Fardiaz, D., Wattimena, G.A., Shetty, K., 1999. Antioxidant activity associated with lipid and phenolic mobilization during seed germination of Pangium edule Reinw. J. Agric. Food Chem. 47, 3158-63.

Anggraini, T., . N., Limber, U., Amelia, R., 2015. Antioxidant activities of some red, black and white rice cultivar from West Sumatra, Indonesia. Pakistan J. Nutr. 14, 112-117. doi:10.3923/ pjn.2015.112.117

Anggraini, T., Amelia, R., Siswardjono, S., 2016. Chemical characteristic of kembang loyang from red, black and white rice. RJPBCS 7, 975-8585.

Chakuton, K., Puangpronpitag, D., Nakornriab, M., 2012. Phytochemical content and antioxidant activity of colored and non-colored Thai rice cultivars. Asian J. Plant Sci. 11, 285293. doi:10.3923/ajps.2012.285.293

Devi, M.K., Das, S.K., 2017. Kinetics of color changes of popped rice during microwave popping: Effect of salt and moisture content. J. Food Process Eng. 40, e12560. doi:10.1111/ jfpe. 12560

Huang, Y.C., Chang, Y.H., Shao, Y.Y., 2006. Effects of genotype and treatment on the antioxidant activity of sweet potato in Taiwan. Food Chem. 98, 529-538. doi:10.1016/j.foodchem. 2005.05.083

Indrasari, SD, W.P.-, 2010. Evaluasi Mutu Fisik, Mutu Giling, dan Kandungan Antosianin Kultivar Beras Merah. pangan.litbang.pertanian.go.id 29.

Lachman, J., Šulc, M., ... K.F.-I.J. of, 2009, U., 2009. Major factors influencing antioxidant contents and antioxidant activity in grapes and wines. Int. J. Wine Res earch 11, 101-121.
Lii, C.Y., Tsai, M.L., Tseng, K.H., 1996. Effect of amylose content on the rheological property of rice starch. Cereal Chem. 73, 415-420.

Loypimai, P., Moongngarm, A., Chottanom, P., 2016. Thermal and $\mathrm{pH}$ degradation kinetics of anthocyanins in natural food colorant prepared from black rice bran. J. Food Sci. Technol. 53, 461-470. doi:10.1007/s13197-015-2002-1

Marsono, Y., 1998. Resistant starch: pembentukan, metabolisme dan aspek gizi-nya. Agritech 18, 29-35.

Pengkumsri, N., Chaiyasut, C., ... C.S.-F.S. and, 2015, U., 2015. Physicochemical and antioxidative properties of black, brown and red rice varieties of northern Thailand. Food Sci. Technol. 35.

Prior, R.L., Cao, G., Martin, A., Sofic, E., McEwen, J., O'Brien, C., Lischner, N., Ehlenfeldt, M., Kalt, W., Krewer, G., Mainland, C.M., 1998. Antioxidant capacity as influenced by total phenolic and anthocyanin content, maturity, and variety of Vaccinium species. J. Agric. Food Chem. 46, 2686-2693. doi:10.1021/jf980145d

Richana, N., Sunarti, T.C., 2004. Karakterisasi sifat fisiko kimiac tepung umbi dan tepung pati dari umbi ganyong, suweg, ubi kelapa dan gembili. J.Pascapanen 1, 29-37.

Soekarto, T., 1981. Penilaian organoleptik, Bharata Karya Aksara Jakarta. IPB (Bogor Agricultural University).

Sompong, R., Siebenhandl-Ehn, S., Linsberger-Martin, G., Berghofer, E., 2011. Physicochemical and antioxidative properties of red and black rice varieties from Thailand, China and Sri Lanka. Food Chem. 124, 132-140. doi:10.1016/j.foodchem. 2010.05.115

Suda, I., Oki, T., Masuda, M., Kobayashi, M., Nishiba, Y., Furuta, S., 2003. Physiological functionality of purplefleshed Sweet Potatoes Containing Anthocyanins and Their Utilization in Foods. Japan Agric. Res. Q. doi:10.6090/jarq.37.167 
Sulistianing, R., 1995. Pembuatan dan Optimisasi Formula Roti Tawar dan Roti Manis Skala Kecil. IPB (Bogor Agricultural University).

Wang, H., Cao, G., Prior, R.L., 1997. Oxygen Radical Absorbing Capacity of Anthocyanins. J. Agric. Food Chem. 45, 304-309. doi:10.1021/jf960421t

Wijaya O, A., 2013. Tepung beras hitam kultivar cempo ireng sebagai sumber antosianin dalam formulasi puff pastry: evaluasi karakteristik fisiko. Skripsi Univ. Katolik Semarang.

Wildan, A., -, E.M., 2010. Uji aktivitas antioksidan penangkap radikal senyawa flavonoid daun kepel (stelechocarpus burahol bl. Hool f. \&amp; th). journal.stifar. 5, 642-649.

Windaryati, T Herlina, dan A.Nafi, 2013. Karakteristik brownis yang dibuat dari komposit tepung gembolo (Dioscorea bulbifera L). J. IIm. Pertan. 1, 25-29.

Xu, J.-J., Zhang, X.-F., Xue, H.-W., 2016. Rice aleurone layer specific OsNF-YB1 regulates grain filling and endosperm development by interacting with an ERF transcription factor. J. Exp. Bot. 67, 6399-6411. doi:10.1093/jxb/ erw409 